\title{
THE IMPACT OF THE 4th INDUSTRIAL REVOLUTION ON THE EMPLOYMENT RELATIONSHIP AND ADAPTIVE SKILLS REQUIREMENTS
}

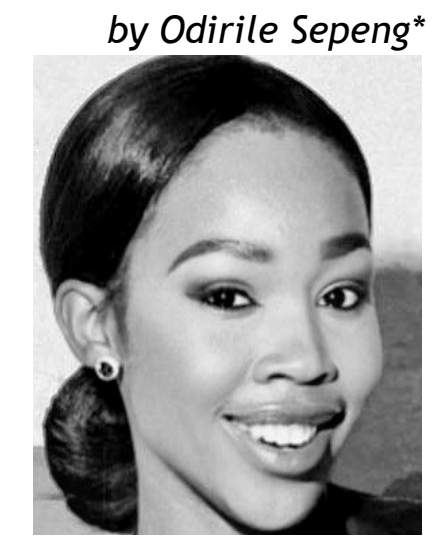

\section{Introduction}

The regulatory framework for labour is significantly influenced and informed by industrialisation, which ultimately shapes society and the future jobs. ${ }^{1}$ Three industrial revolutions were catalysts of industrialisation throughout world history. The first industrial revolution steam powered factories, the second was the application of science to mass production and manufacturing, and the third was the start into digitalisation. ${ }^{2}$ Presently, the 4IR gives attention to technological advancements which pose a threat to replacing human capital in the production process as it also threatens to blur the lines between reality and the virtual world. ${ }^{3}$ Technological developments

* Third year LLB student, University of Pretoria.

1 E Potenza 'All that glitters - what is industrialisation?' https://www.sahistory. org.za/archive/all-glitters-what-industrialisation-emilia-potenza (accessed 29 May 2019). See also M Weiss 'Re-inventing labour law?' In G Davidov \& B Langille (eds) The idea of labour law (2011) 234.

2 K Schwab 'The fourth industrial revolution' https://www.britannica.com/topic/ The-Fourth-Industrial-Revolution-2119734 (accessed 20 August 2019).

3 K Schwab 'The fourth industrial revolution' World Economic Forum on Africa 19 July 2016 https://www.weforum.org/about/the-fourth-industrial-revolutionby-klaus-schwab (accessed on 20 August 2019). 
have changed the traditional work organisation drastically as labour force is no longer homogeneous but rather segmented and fragmented into marginal groups and core groups. Furthermore, it is influenced by the rise of new forms of work and less traditional employment. ${ }^{4}$ This article reflects on the possible future of labour law as a response to industrialisation, particularly the 4IR.

First, I discuss the origin of the industrial revolution by reflecting on the first three industrial revolutions and the present 4IR. Second, I reflect on; 1) the possible impact of the 4IR on the employment relationship and 2 ) the new and/or adaptive skills requirements. Third, I present recommendations to respond to the fast-changing pace of labour and industrialisation suggested by the World Economic Forum (WEF). I thereafter conclude that the 4IR may be used as a vehicle to promote a socially affirmative interpretation of fairness in the labour context. This promotes a constitutional obligation to protect the interests of workers, in light of technological advancement, that have the potential to widen the income inequality gap.

\section{The historical development of the industrial revolutions}

The series of events that best describes the transformation of the first three industrial revolution is mechanisation of production; the introduction of mass production, and the digital revolution. ${ }^{5}$ The industrial revolution introduces new technologies and perspectives of the changing world in the economic and social orders. The first three industrial revolutions can be equated as the mechanisation of production; introduction of mass production and digital revolution. ${ }^{6}$ The first industrial revolution is known as 'the age of mechanical production', where the world relied less on agriculture and shifted towards manufacturing. This saw the rise of middle-class skilled workers. ${ }^{7}$ The second industrial revolution is known as 'the age of science and mass production' and this era created more jobs for skilled workers than the first industrial revolution. ${ }^{8}$ Steel, oil and electricity were used to power mass production. ${ }^{9}$ The third industrial revolution is known as 'the digital revolution' where electronics and information technology began to automate production and take

4 MM Botha \& E Fourie 'Decolonising the labour law curriculum in the new world of work' (2019) 28 Tydskrif vir Hedendaagse Romeins-Hollandse Reg 13.

5 Trailhead 'The four industrial revolutions' https://trailhead.salesforce.com/en/ content/learn/modules/learn-about-the-fourth-industrial-revolution/meet-thethree-industrial-revolutions.

6 Trailhead (n 5).

7 Trailhead (n 5).

8 Trailhead (n 5).

9 Trailhead (n 5). 
supply chains global. ${ }^{10}$ The progressive transformation from one revolution to another saw more people move into the cities as a result of mechanical production. Today, the 4IR is looming before us and it is characterised by machine learning and artificial intelligence. ${ }^{11}$

\subsection{What is the 4IR?}

For purposes of convenience the Fourth Industrial Revolution is referred to as $4 I R$. The $4 I R$ is characterised by technologies such as artificial intelligence, autonomous vehicles as well as the internet that has intergraded into our day to day lives. ${ }^{12}$ It builds on the digital revolution to enable the co-existence of physical and virtual production systems that are able to harmoniously co-operate on a global level. ${ }^{13}$ The difference between the third and 4IR, is the existing gap between digital, physical and biological orders that are now becoming one, as technology rapidly changes and integrates into human life. The unique additional extra features that the 4IR displays is the enhancement and possible opportunity to assist policy-makers, leaders and income groups to utilise technology to create a future human life. ${ }^{14}$ The revolution offers faster and efficient productivity, easily accessible connectivity and a general improvement in workplaces. ${ }^{15}$ This has reduced costs for human labour. ${ }^{16}$

It is further noted that the industrial revolutions had an impact on industrialisation in South Africa. ${ }^{17}$ Consequently, South Africa has drastically moved away from dependence on the agricultural and manufacturing sectors as significant drivers of economic growth. Research suggests that South Africa is currently a service economy, as the services sector contributes more than $45 \%$ towards the South African gross domestic product (GDP). ${ }^{18}$ The increased efficiency in production that is promised by the impending 4IR will incentivise the organisations in the services industry to substitute labour for capital. $^{19}$

This means that the implementation of 4IR inspired technology in the workplace would have a direct impact on the labour force and the

10 Trailhead (n 5).

11 Trailhead (n 5).

12 Trailhead (n 5).

13 Schwab (n 2) 12

14 Schwab (n 2) 17.

15 Regus 'The workplace revolution' https://www.iwgplc.com/WhitePapers/theworkplace- revolution-regus-january-2017.pdf (accessed 10 October 2019)

16 Schwab (n 2) 23.

17 E Potenza 'All that glitters - What is industrialisation?' https://www.sahistory. org.za/archive/all-glitters-what-industrialisation-emilia-potenza (accessed 29 May 2019).

18 'South Africa's GDP' https://www.southafricanmi.com/south-africas-gdp.html (accessed 30 May 2019).

19 Schwab (n 2) 16. 
employment relationship that exists between employers and employees.

\section{The impact of the 4IR on the employer- employee relationship}

The traditional cornerstone of labour law comprises of an indefinite contract, with a single employer centred around a fundamental concept of permanent employment. This contract, which is typified by employees traditionally engaging in a workplace over which the employer organises work, exercises physical control and directs how employees should do it, is being abraded. ${ }^{20}$ Labour law has traditionally been concerned with the unequal bargaining power in an employment relationship. ${ }^{21}$ As such, Botha and Fourie recognise that such inequalities negatively impact an employee's livelihood. ${ }^{22}$ Rycroft and Le Roux advocate for fair labour practices in favour of the employee and their view is influenced by the changing 4IR. ${ }^{23}$

Contemporarily, and in the future, it is likely that work will be performed by someone who receives instruction on-line, works from home with full autonomy, delivers the agreed services or product(s) on-line, and is paid on-line. ${ }^{24}$ According to Thompson, these more propitious forms of practice(s) may have advantages for those employees aspiring for maximum flexibility, however, they predominantly offer less protection to workers than the traditional model of employment. ${ }^{25}$ The decolonisation of labour law would see the employment relationship achieve more than merely a masterservant relationship which has traditionally stifled the contracting of an employment relationship. ${ }^{26} \mathrm{New}$ forms of 'worker' have emerged, such as the 'zero hour' contract, the 'Uber driver' and the 'e-lancer' who are based on the road and at home. ${ }^{27}$ The 4IR introduces new risks, conditions and new working environments through innovative technology. 28 The emergence of the 'gig economy' in which services are provided on demand whilst being driven by a technology platform, has brought the discussion on contingent forms of practice into sharp focus. ${ }^{29}$ Therefore, the traditional employment relationship needs to

20 A Van Niekerk \& N Smit (ed) Law@work (4th ed) (2018) 35.

21 AJ Rycroft \& R Le Roux 'Decolonising the labour law curriculum' (2017) 38 Industrial Law Journal 1483.

22 Botha \& Fourie (n 4) 6.

23 Rycroft \& Le Roux (n 21) 1482.

24 Van Niekerk \& Smit (n 20) 5.

25 C Thompson 'The changing nature of employment' (2003) 24 Industrial Law Journal 1815.

26 Rycroft and Le Roux (n 21) 1483.

27 Botha \& Fourie (n 4) 13.

28 Botha and Fourie (n 4) 12.

29 For example, Uber transport. See also Van Niekerk \& Smit (n 20) 5. 
increasingly be on scalable adaptability as well as empowering people rather than corporation as seen with the first three revolutions. This means that the human resource practitioners will take on a critical role in articulating and defining the terms and conditions of work contracts to ensure that the labour experience promotes a more flexible work environment and accommodates artificial intelligence and the advancement of human capital. ${ }^{30}$ Weiss argues that employment labour is not a commodity and therefore the employment relationship should promote the employee's human dignity. ${ }^{31}$ The International Labour Organisation's (ILO) recommendations propel a sustainable development of the labour force through economic growth and improved distribution of income. ${ }^{32}$ Le Roux rightly refers to this as the sustainable employment and good governance, which encapsulates the best interests of the parties involved. ${ }^{33}$ Weiss further recognises the redundancy of traditional modes of employment and suggests that the labour market is moving into virtual entities as embodied by the 4IR. ${ }^{34}$ The concern is employing labour law to adapt to the new order, whilst simultaneously protecting the employee's interest. ${ }^{35}$

\section{The impact of the 4IR on new and adaptive skills requirement}

The fast-changing evolution of innovative technology and its disruptive impact on the development on the socio-economic order leads to the transformation of industries and how businesses structure themselves. ${ }^{36}$ The employment relationship will be changed, as employers will demand current and innovative skills. Employees will also be forced to upskill and develop new sets of skills. An example of this concept is the introduction of machine learning and robots. ${ }^{37}$ This phenomenon will not necessarily eradicate all professions however, there will be a substitution of certain tasks carried out by such

30 Botha and Fourie (n 4) 12.

31 Weiss (n 1) 44.

32 As above.

33 Rycroft \& Le Roux (n 21) 1129.

34 Weiss (n 1) 45. Although Weiss does not directly refer to the 4IR, he mentions those factors that characterise the impending 4IR such as virtualisation, technological changes, less traditional employment, and new forms of work.

35 Botha and Fourie ( $\mathrm{n}$ 4) 7.

36 L Omarjee Fin 24 'We can't predict job losses due to the 4th industrial revolution -labour minister' 15 March 2019 https://www.fin24.com/Economy/Labour/wecant-predict-job-losses-due-to-the-4th-industrial-revolution-labour-minister20190315-2 (2 September 2019).

37 World Economic forum 'The future of jobs, employment, skills and workforce strategy for the fourth industrial revolution' http://www3.weforum.org/docs/ WEF_Future_of_Jobs.pdf (2 September 2019) 58. 
machines. This will see more and more employees with more time and the opportunity to adapt and learn new skills. ${ }^{38}$

Tshilidzi Marwala used the example of the introduction of artificial intelligence on stock trading, where human traders were replaced by artificial intelligent traders. ${ }^{39}$ The emotional aspect is therefore removed from the markets and the decisions are purely objective and therefore made on data only. Trade markets have seen the shift of relying on human skills of shouting aloud and using height as an advantage to be seen when shouting prices. ${ }^{40}$ However, human beings no longer control the stock market as many are using computers to trade in stock markets. This has seen a far more efficient stock trading market. ${ }^{41}$ In the same light, professionals in the banking sector traditionally needed accounting skills. However, now the banking sector should expand their skills as future bankers must have an understanding for technology. This is evident in the closing of walk in bank branches in order to accommodate an even quicker, convenient and efficient online banking method. ${ }^{42}$

Such adaptability of skillsets to the change of industrialisation is through multi-disciplinary education, where human and social sciences accommodate science and technology. This includes skills such as social skills, complex problem solving skills, content skills, process skills, systems skills, cognitive abilities and physical skills. ${ }^{43}$ । recommend the section 213 of the Labour Relations Act (the LRAct) definition of an employee be reconsidered to include the upcoming changes as introduced by the $4 \mathrm{IR} .{ }^{44}$ In recognising that labour law does not exist in isolation, together with Weiss, Rycroft and Le Roux firmly hold that the law should respond to the unequal societal labour issues including minimum wage, parental leave, disputes and strike actions. $^{45}$

\section{Conclusion: Recommendations}

The need for rapid adjustment to the new disrupted sphere is vital for all stakeholders. Taking government as an example, it would be advisable to consider the inclusion of innovative approaches within

38 Omarjee (n 36).

39 A Chauke 'Jobs and skills in the fourth industrial revolution' 18 December 2018 https://www.sanews.gov.za/features-south-africa/jobs-and-skills-fourthindustrial-revolution (2 September 2019).

40 As above.

41 As above.

42 As above.

43 As above.

44 The Labour Relations Act 66 of 1995.

45 Staff Writer Business Tech ' 3 manor new labour laws that every South African needs to know about' https://businesstech.co.za/news/business/264791/3major-new-labour-laws-that-every-south-african-needs-to-know-about/

(accessed 15 October 2019). 
education and labour-related regulation and policy making. ${ }^{46}$ This would entail that a new set of skills would be developed. When looking at education and training institutions, it would be vital to look into new business models and strategies in providing products for employees who need to apply new skill sets, entrepreneurs who will require an innovative outlook regarding product and service delivery, as well as the private and public sector. ${ }^{47}$ It would be recommendable for businesses to invest in the new opportunities when developing talent because looking into the future, workforce will be the heart of a sustainable business development. It is finally dawning on firms that, the days of merely waiting on human capital to serve in the firm are soon ending. They would now have to adopt a new outlook in achieving their skills and talents out of necessity and with a sense of urgency. The WEF recommends seven immediate and long-term ways to respond to the possible impact of the 4IR on both the employment relationship and adaptive skills. ${ }^{48}$

Businesses can reinvent the Human Resources function by managing skills disruption as a matter of urgency. When looking at talent development, it can no longer be deemed as a long-term issue that could be resolved by traditional counter-fit solutions that were tested in the past, or by merely substituting talents. It is vital to consider proactive and innovative skill-development as a response to the changing industries. This would require that the HR departments of the various firms delegate to identify skill gaps and advise the organisation to shift their strategies to optimise on transformative trends. ${ }^{49}$ Secondly, businesses should make use of data analytics in order to build a new approach to workforce planning and talent management in order to improve data forecasting. By making use of such data, firms would be able identify and optimise on new and emerging skills as a form of responding to the changing working environment. 50

Furthermore, businesses can benefit from a diverse and talented workforce. This diversity can be in terms of age, gender, race or sexual orientation. The use of technology can assist businesses to identify the neglected biases in recruitment processes. This can be achieved through advertisement or better understanding of the workplace culture in order to stimulate a better working environment. With the recent changes and blurs in physical and organisational boundaries, it would be vital for firms to consider capitalising on flexible working arrangements and encourage online talent platforms. The way in which firms usually manage people's 
performance will change as more people are able to connect and collaborate independently through digital frameworks. Such collaboration will see the need for modern digital trade unions and updated regulatory provisions, which suit the changing working environments. ${ }^{51}$

Technological trends introduced by the 4IR will introduce many new cross-functional roles for which employees will need both technical and social and analytical skills. Therefore, it would be recommendable for businesses to rethink about education systems as $65 \%$ of children who are in the primary educational phase will enter the workforce when the job types have been created. ${ }^{52}$ Reactive work, as a concept, will cease to exist. Instead, it will be replaced by discretionary ability and out of the box thinking.

It would be vital for firms to also incentivise on lifelong learning. When looking at it from a company perspective, the firms would need to continuously upskill and reskill their employees. ${ }^{53}$ The collaboration between the public and private sectors on talent issues will offer firms the opportunity to partner up and develop future skills and employment needs as opposed to seeing each other as competition. Businesses will need to engage with government on strategies that shift away from redundant skills between the sectors and address cost concerns and social stability. ${ }^{54}$

51 As above.

52 World Economic forum 'Releasing human potential in the fourth industrial revolution, an agenda for leaders to shape the future of education, gender and work' http://www3.weforum.org/docs/WEF_EGW_Whitepaper.pdf (2 September 2019) 45.

53 World Economic forum (n 37) 59.

54 World Economic forum (n 37) 62. 